\title{
Cureus
}

\section{Mitral Valve Infective Endocarditis due to Streptococcus pyogenes: A Case Report}

\author{
Cristina Sarda $^{1}$, Giulia Magrini ${ }^{2}$, Sfefano Pelenghi ${ }^{3}$, Annalisa Turco ${ }^{4}$, Elena Seminari ${ }^{5}$ \\ 1. Infectious Diseases, Fondazione IRCCS Policlinico San Matteo, Pavia, ITA 2. Cardiology, Fondazione \\ IRCCS Policlinico San Matteo, Pavia , ITA 3. Cardiac Surgery, Fondazione IRCCS Policlinico San Matteo, \\ Pavia, ITA 4. Cardiology, Fondazione IRCCS Policlinico San Matteo, Pavia, ITA 5. Infectious Diseses, \\ Fondazione IRCCS Policlinico San Matteo, Pavia, ITA
}

$\square$ Corresponding author: Elena Seminari, elenaseminari5@gmail.com Disclosures can be found in Additional Information at the end of the article

\section{Abstract}

Infective endocarditis (IE) due to group A $\beta$-hemolytic streptococcus (Streptococcus pyogenes) has rarely been reported in the literature. We herein report a Streptococcus pyogenes native mitral valve endocarditis in a young patient and a review of the literature. The patient had a native mitral valve endocarditis with vegetation; his hemodynamic stability and a short course of antibiotic treatment prevented urgent surgery on the mitral valve. He was previously treated with cefixime and azithromycin for four days and then, upon hospital admission, with vancomycin plus amoxicillin-clavulanate. After the diagnosis of IE due to Streptococcus pyogenes, treatment with gentamicin ( $3 \mathrm{mg} / \mathrm{kg}$ daily) and ampicillin (12 $\mathrm{g} /$ day) was implemented. The patient underwent weekly echocardiographic evaluations during antibiotic treatment to document the resolution of the vegetations. He was discharged to home in good clinical conditions after a four-week course of antibiotic treatment.

Categories: Cardiac/Thoracic/Vascular Surgery, Cardiology, Infectious Disease

Keywords: infective endocarditis, streptococcus pyogenes

\section{Introduction}

Infective endocarditis (IE) due to group A, B, C, or G streptococci, including the Streptococcus anginosus group (S.constellatus, S. anginosus, and S. intermedius) is relatively rare [1]. IE due to group A $\beta$-hemolytic streptococcus (Streptococcus pyogenes) has rarely been reported in the literature. We herein report a Streptcoccus pyogenes native mitral valve endocarditis in a young patient along with a review of the literature.

Received 12/31/2018 Review began 01/04/2019 Review ended 03/28/2019 Published 04/15/2019

\section{(C) Copyright 2019}

Sarda et al. This is an open access article distributed under the terms of the Creative Commons Attribution License CC-BY 3.0., which permits unrestricted use, distribution, and reproduction in any medium, provided the original author and source are credited.

\section{Case Presentation}

A 16-year-old Italian boy was admitted with a seven-day history of persistent fever and chills associated with painful swelling of the right shoulder and pharyngitis. He had previously received four days of cefixime and azithromycin treatment. He did not report any recent dental treatment, surgery, or drug abuse. His past cardiac history was unremarkable. The patient was in good general conditions and had normal vital signs (blood pressure: 125/65 $\mathrm{mmHg}$, regular heart rate: 84 beats/minute). He had a temperature of $100.4^{\circ} \mathrm{F}\left(38^{\circ} \mathrm{C}\right)$. Cardiovascular examination revealed a systolic heart murmur $2 / 6$ at the mesocardium. The pharynx was normal and minimal acne was observed on the skin. Blood tests indicated neutrophilic leukocytosis (white blood cell count: 13x 103/ $\mathrm{LL}$; neutrophils: $9.7 \times 103 / \mu \mathrm{L}$ ) as well as elevated lactate dehydrogenase $(266 \mathrm{mU} / \mathrm{mL})$ and $\mathrm{C}$ reactive protein (CRP; $18 \mathrm{mg} / \mathrm{dL}$ ). The urine analysis was negative for infection. The electrocardiography (ECG) demonstrated sinus tachycardia, and the 


\section{Cureus}

chest x-ray was normal. A bone marrow aspirate was performed to exclude hematological malignancies. Two sets of blood cultures were drawn, and empirical treatment with amoxicillin/clavulanate plus vancomycin was started. Blood cultures were found to be positive for gram-positive cocci in chains, which were later identified as streptococcus group A (Streptococcus pyogenes). The patient was admitted to the Infectious Disease Department and ceftriaxone ( $2 \mathrm{~g}$, twice daily) plus ampicillin (12g/day) were started. The transesophageal echocardiogram (TEE) documented moderate mitral regurgitation and multiple mobile filamentous structures attached to the posterior mitral leaflet (PML) of $1.1 \mathrm{~cm}$ in length suggestive of vegetation (Figure $1 A-11$ ).

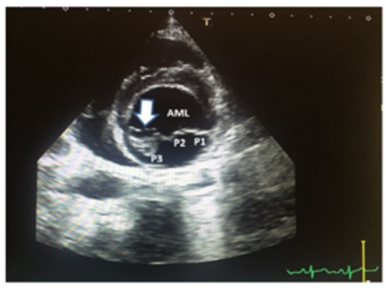

A
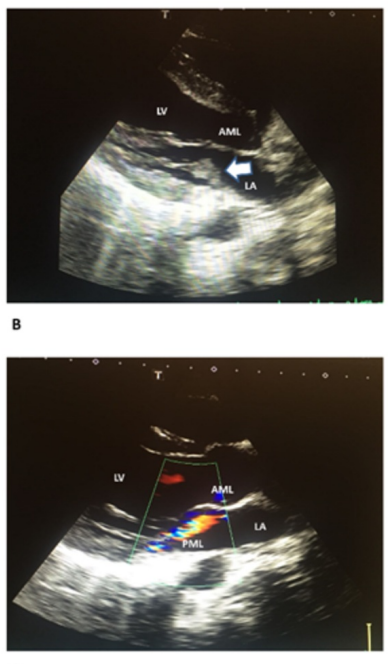

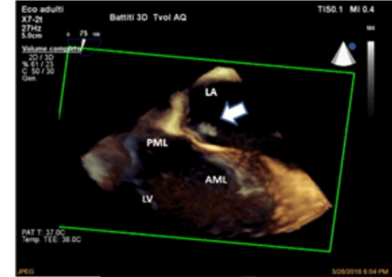

D
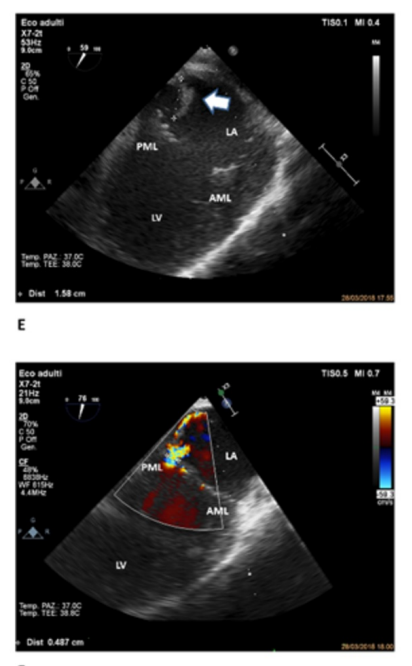
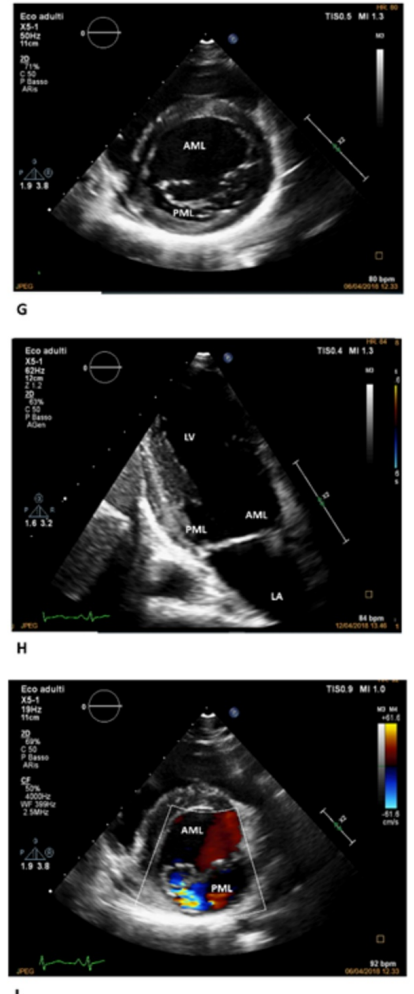

\section{FIGURE 1: Sequential echocardiographic assessments}

Panel A: Transthoracic two-dimensional echocardiography - parasternal short axis view of the mitral valve. Arrow showing vegetation on the medial portion of the posterior mitral leaflet (P3) Panel B: Transthoracic two-dimensional echocardiography - parasternal long axis view. Arrow showing vegetation on the posterior mitral leaflet. Panel C: Transthoracic two-dimensional echocardiography - parasternal long axis view with color flow mapping displaying a mild mitral valve regurgitation. Panel D: Three-dimensional transesophageal view of the mitral valve. Arrow showing vegetation on the posterior mitral leaflet. Panel E: Transesophageal off-axis view of the mitral valve. Arrow showing vegetation on the posterior mitral leaflet. Panel F: Transesophageal offaxis view of the mitral valve with color flow mapping showing a moderate mitral regurgitation (vena contracta width $4.87 \mathrm{~mm}$ ). Panel G: Transthoracic two-dimensional echocardiography - parasternal short axis view of the mitral valve. Resolution of the vegetation that was detected at the P3 level. Panel H: Transthoracic two-dimensional echocardiography - apical two chamber view. Anterior and posterior mitral leaflets appear intact without vegetation. Panel I: Transthoracic twodimensional echocardiography - parasternal short axis view of the mitral valve with color flow mapping showing mild residual mitral regurgitation.

Abbreviations: AML, anterior mitral leaflet; LA, left atrium; LV, left ventricle; PML, posterior mitral leaflet. P1 (lateral), P2 (middle), and P3 (medial) are the scallops of the posterior mitral leaflet. 


\section{Cureus}

The hemodynamic stability of the patient (he had normal values for atrial natriuretic peptide and no signs of heart failure) and the short course of antibiotic treatment were the reasons for not performing urgent surgery on the mitral valve after consultation with cardiac surgeons. Gentamicin (3mg/kg daily) was started instead of ceftriaxone on day seven. His abdominal ultrasonography was negative for liver or splenic embolisms. Painful erythematous nodules (2 to $3 \mathrm{~mm}$ ) were observed on the skin of the right sole, suggestive of secondary lesions. No other skin lesions appeared during the following days, and the neurological examination was steadily normal. The patient underwent weekly ECG evaluations during antibiotic treatment.

A second TEE done on the 12th day of antibiotic therapy found worsening of the endocarditis and growth of the vegetative lesions on the PML. On the 14th day, a cardiac magnetic resonance scan excluded either concomitant rheumatic heart disease or peri-valvular abscess due to Streptococcus pyogenes. At the ECG exams on the 19th and 25th days of hospitalization, the vegetant lesions were not observed (Figure $1 \mathrm{G}-\mathrm{I}$ ). Gentamicin treatment was continued for two weeks, ampicillin for four weeks, and then the patient was discharged. At the clinical control checkup six months later, the patient was asymptomatic with normal vital signs. A blood test revealed normal white blood cells (WBC) count and CRP levels. Transthoracic echocardiography (TTE) showed a low-grade mitral insufficiency consistent with previous endocarditis of posterior commissure of the mitral valve with normal left ventricular ejection fraction.

\section{Discussion}

Group A $\beta$-hemolytic Streptococcus pyogenes colonizes the throat and/or skin, and it is responsible for several purulent infections including pharyngitis, impetigo, necrotizing fasciitis, and streptococcal toxic shock syndrome [1]. Bloodstream infections caused by Streptococcus pyogenes come from a primary source that may be cellulitis, pharyngitis, endometritis, pneumonia, or other localized pyogenic infections [1].

In our case, the source of bacteremia may have been an upper respiratory tract infection, pharyngitis, or skin lesions (acne, folliculitis). Group A Streptococcus pyogenes may induce autoimmune diseases such as acute post-streptococcal glomerulonephritis, rheumatic fever, and rheumatic heart disease; IE has rarely been reported. Based on this, a literature research was performed using PubMed without restriction on search dates. Reports were identified on PubMed using the following keywords: 'infective endocarditis and Streptococcus pyogenes' or 'Streptococcus pyogenes endocarditis'. The literature search was limited to English language articles. Studies not available online were excluded.

Globally, including the present case, 39 cases of endocarditis caused by Streptococcus pyogenes in children and adults have been reported since 1940 [2-14] (Table 1).

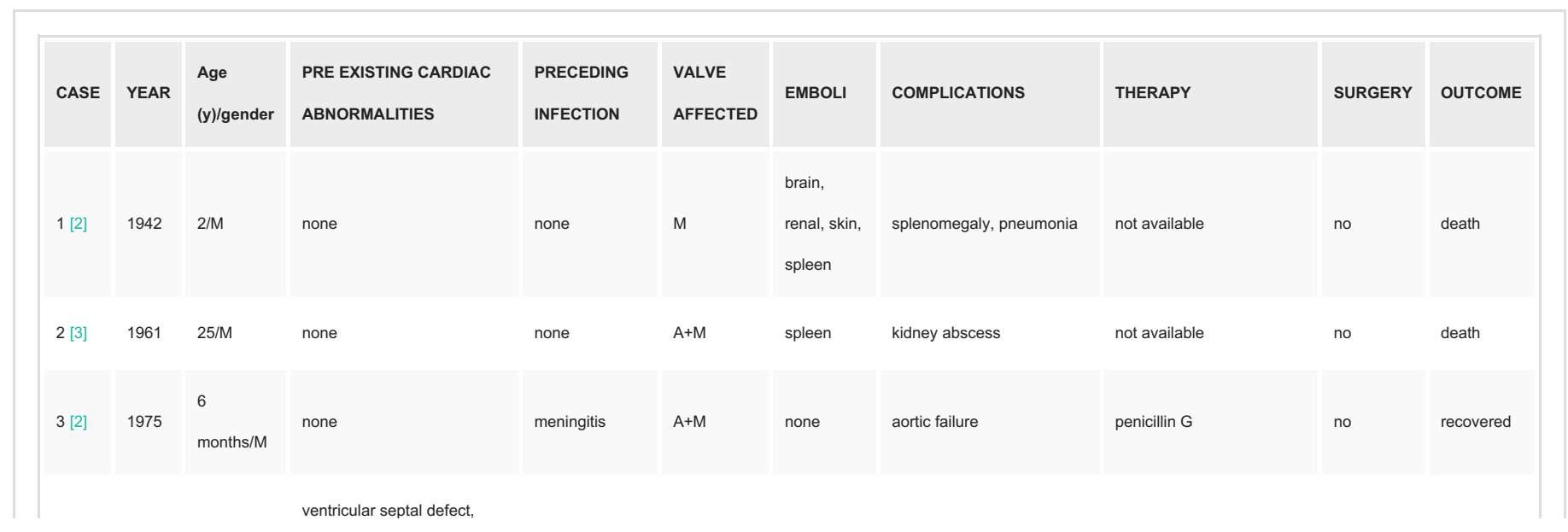




\section{Cureus}

\begin{tabular}{|c|c|c|c|c|c|c|c|c|c|c|}
\hline 4 [2] & 1976 & $14 / \mathrm{M}$ & aortic stenosis & tonsillitis & A & none & myocardial abscess & not available & no & death \\
\hline $6[2]$ & 1980 & 16/M & none & pharyngitis & A & $\begin{array}{l}\text { renal, } \\
\text { peripheral }\end{array}$ & ARDS & not available & no & recovered \\
\hline $7[2$ & 1984 & $2 / \mathrm{M}$ & pulmonary artery stenosis & pharyngitis & $A+M$ & $\begin{array}{l}\text { brain, } \\
\text { spleen }\end{array}$ & cardiac failure & $\begin{array}{l}\text { penicillin G; nafcillin and } \\
\text { gentamicin }\end{array}$ & no & death \\
\hline $8[2]$ & 1988 & $4 / \mathrm{M}$ & none & varicella & A & none & para-aortic abscess & $\begin{array}{l}\text { cefuroxime, cefaclor, } \\
\text { ampicillin and gentamicin }\end{array}$ & no & death \\
\hline $9[2]$ & 1988 & 4/F & none & none & A & none & polyarthritis & cefotaxime, penicillin $\mathrm{G}$ & yes & recovered \\
\hline $10[4]$ & 1991 & $63 / F$ & none & pharyngitis & none & none & none & penicillin $\mathrm{G}$ and penicillin $V$ & no & recovered \\
\hline $11[4]$ & 1991 & 65/M & $\begin{array}{l}\text { coronary-artery disease and } \\
\text { severe arteriosclerosis }\end{array}$ & $\begin{array}{l}\text { arthritis, } \\
\text { cellulitis }\end{array}$ & M & $\begin{array}{l}\text { brain, } \\
\text { Janeway } \\
\text { lesions }\end{array}$ & none & penicillin $\mathrm{G}$ and penicillin $\mathrm{V}$ & no & recovered \\
\hline $12[4]$ & 1991 & 69/F & $\begin{array}{l}\text { aortic- and pulmonary-valve } \\
\text { prostheses }\end{array}$ & none & none & $\begin{array}{l}\text { skin, roth } \\
\text { lesion }\end{array}$ & none & $\begin{array}{l}\text { vancomycin and } \\
\text { gentamicin }\end{array}$ & no & recovered \\
\hline $13[4]$ & 1991 & $55 / \mathrm{M}$ & mitral regurgitation & none & M & none & none & $\begin{array}{l}\text { cefazoline, ampicillin, } \\
\text { penicillin } \vee\end{array}$ & no & recovered \\
\hline 14 [2] & 1992 & $3 / \mathrm{F}$ & none & none & $\mathrm{M}$ & brain, skin & $\begin{array}{l}\text { left-side hemiparesis, } \\
\text { pericardial effusion, mitral } \\
\text { regurgitation }\end{array}$ & penicillin $\mathrm{G}$ & no & recovered \\
\hline 15 [2] & 1994 & 20/M & none & none & M & none & none & not available & no & death \\
\hline 16 [2] & 1998 & $14 / \mathrm{M}$ & none & none & $\mathrm{M}$ & brain & cerebral infarction & penicillin, gentamycin & no & recovered \\
\hline 17 [2] & 1999 & $\begin{array}{l}5 \\
\text { months/M }\end{array}$ & none & varicella & M & skin & respiratory failure, purpura & $\begin{array}{l}\text { ceftriaxone and } \\
\text { vancomycin, ampicillin, } \\
\text { penicillin }\end{array}$ & yes & recovered \\
\hline 18 [2] & 2000 & $3 / \mathrm{M}$ & none & varicella & A & $\begin{array}{l}\text { peripheral, } \\
\text { skin }\end{array}$ & $\begin{array}{l}\text { joint pain, aortic } \\
\text { insufficiency, CHF }\end{array}$ & penicillin and gentamycin & yes & recovered \\
\hline 19 [2] & 2000 & $4 / \mathrm{M}$ & none & none & A & skin & $\begin{array}{l}\text { mitral regurgitation, } \\
\text { necrosis of toes }\end{array}$ & not available & yes & recovered \\
\hline 20 [2] & 2000 & $2 / \mathrm{M}$ & none & varicella & A & brain, skin & $\begin{array}{l}\text { aortic root abscess, aortic } \\
\text { valve perforation }\end{array}$ & not available & yes & recovered \\
\hline $21[5]$ & 2004 & $11 / \mathrm{M}$ & none & varicella & A & $\begin{array}{l}\text { brain, } \\
\text { renal, } \\
\text { spleen }\end{array}$ & aortic failure & clarithromycin & yes & recovered \\
\hline $22[6]$ & 2008 & 68/M & none & $\begin{array}{l}\text { left lower limb } \\
\text { weakness }\end{array}$ & A & none & $\begin{array}{l}\text { meningitis, heart-failure, } \\
\text { sepsis }\end{array}$ & ceftriaxone and gentamicin & no & death \\
\hline $23[7]$ & 2012 & 71/M & hypertension & none & $\mathrm{A}, \mathrm{M}, \mathrm{T}$ & $\begin{array}{l}\text { renal, } \\
\text { spleen }\end{array}$ & $\begin{array}{l}\text { aortic regurgitation, } \\
\text { coronary artery disease }\end{array}$ & penicillin $\mathrm{G}$ & yes & recovered \\
\hline 24 [2] & 2014 & 6/F & patent foramen ovale, atrial & $\begin{array}{l}\text { erythematous } \\
\text { rash, }\end{array}$ & $A, M$ & skin, brain & aortic root abscess, & $\begin{array}{l}\text { ceftriaxone, vancomycin } \\
\text { and meropenem, and }\end{array}$ & no & recovered \\
\hline
\end{tabular}




\section{Cureus}

\begin{tabular}{|c|c|c|c|c|c|c|c|c|c|c|}
\hline & & & septal defect & pharyngitis & & & arrhythmia & gentamycin & & \\
\hline 25 [2] & 2014 & 8 & none & pharyngitis & T & brain & $\begin{array}{l}\text { respiratory failure, sepsis, } \\
\text { multi-organ failure }\end{array}$ & penicillin and clindamycin & no & recovered \\
\hline $26[8]$ & 2010 & 64/M & none & $\begin{array}{l}\text { urinary tract } \\
\text { infection } \\
\text { pharyngitis }\end{array}$ & none & none & none & $\begin{array}{l}\text { gentamicin, } \\
\text { benzylpenicillin }\end{array}$ & no & recovered \\
\hline 27 [9] & 2017 & 68/M & none & arthritis & none & none & heart and renal failure & $\begin{array}{l}\text { ceftriaxone, meropenem, } \\
\text { ampicillin and clindamycin, } \\
\text { cefazolin }\end{array}$ & no & recovered \\
\hline $\begin{array}{l}28 \\
{[10]}\end{array}$ & 2001 & 73/F & none & n.d. & A & none & cardiac complications & not available & no & recovered \\
\hline $\begin{array}{l}29 \\
{[10]}\end{array}$ & 2005 & 64/M & none & n.d. & A & none & cardiac complications & not available & yes & recovered \\
\hline $\begin{array}{l}30 \\
{[10]}\end{array}$ & 2006 & 33/M & none & n.d. & T & brain & none & not available & no & recovered \\
\hline $\begin{array}{l}31 \\
{[10]}\end{array}$ & 2008 & $68 / F$ & none & n.d. & M & none & cardiac complications & not available & yes & death \\
\hline $\begin{array}{l}32 \\
{[10]}\end{array}$ & 2011 & $24 / \mathrm{M}$ & none & n.d. & none & none & cardiac complications & not available & no & recovered \\
\hline $\begin{array}{l}33 \\
{[10]}\end{array}$ & 2013 & 39/M & none & n.d. & A & yes & cardiac complications & not available & no & death \\
\hline $\begin{array}{l}34 \\
{[10]}\end{array}$ & 2013 & $51 / \mathrm{M}$ & none & n.d. & A & none & cardiac complications & not available & yes & recovered \\
\hline $\begin{array}{l}35 \\
{[11]}\end{array}$ & 2014 & $5 / \mathrm{M}$ & none & gastroenteritis & M & none & none & amoxicillin and gentamycin & no & recovered \\
\hline $\begin{array}{l}36 \\
{[12]}\end{array}$ & 2015 & $42 / \mathrm{M}$ & none & $\begin{array}{l}\text { vasculitis } \\
\text { arthritis }\end{array}$ & T & lung, brain & pulmonary thrombosis & $\begin{array}{l}\text { ceftriaxone and } \\
\text { gentamycin }\end{array}$ & No & recovered \\
\hline $\begin{array}{l}37 \\
{[13]}\end{array}$ & 2017 & 77/M & $\begin{array}{l}\text { prosthesis, atrial fibrillation, } \\
\text { mellitus type } 2\end{array}$ & otitis media & M & brain & meningitis & ceftriaxone & No & recovered \\
\hline $\begin{array}{l}38 \\
{[13]}\end{array}$ & 2017 & $80 / \mathrm{F}$ & none & meningitis & M & n.d. & meningitis & ampicillin and clindamycin & No & recovered \\
\hline
\end{tabular}

\section{TABLE 1: Streptococcus pyogenes endocarditis cases from the literature review}

Abbreviations: ARDS, acute respiratory distress syndrome; $\mathrm{CHF}$, chronic heart failure; Heart valves: A, aortic; $\mathrm{M}$, mitral; $\mathrm{T}$, tricuspid; n.d., no data.

Out of the 39 cases of Streptococcus pyogenes endocarditis identified, 30 were in men (77\%). 
Ages ranged from four months to 80 years with a median age of 32 years. Five patients were intravenous drug users. Pre-existing heart defects were known in $22.2 \%$ of the cases. Skin lesions were the predisposing infection in eight cases (20.5\%), while pharyngitis was described in seven patients (18\%). In four cases (10\%), joint pain and arthritis were reported as the first manifestation. Ten cases (26\%) had no known preceding infections. Valves on the left side were most commonly involved (88\%). Embolic phenomenon occurred in 20 cases (51\%) with the central nervous system and skin being the most frequent sites. Ten patients (26\%) had cardiac surgery, and one of them died after surgery (10\%). The mortality rate was $24 \%$ (62.5\% before 1990 and $15.4 \%$ after 1990) and was mainly due to cardiac failure and/or septic shock; most patients recovered after antibiotic therapy. Compared to Streptococcus pneumonia infectious endocarditis (IE) for which the potential value of valve replacement in preventing early death has been demonstrated, in cases of Streptococcus pyogenes IE, the role for surgery is less mandatory [15]. Most patients treated with antibiotic therapy alone had a favorable outcome (84\%). Notably, five of the nine patients that died did so before the 1990s; the microbiological and instrumental techniques from that period are considered obsolete. Based on the limited published data, penicillin G, ampicillin, or ceftriaxone administered intravenously for four weeks are reasonable treatments for Streptococcus pyogenes IE. The addition of gentamicin to penicillin or ceftriaxone for at least the first two weeks of a four-week course of antimicrobial therapy for group B, C, and G streptococcal IE may be considered [16], while another option could be daptomycin plus ampicillin based on the severity of the disease. Vancomycin is reasonable only for patients who are unable to tolerate a beta-lactam antibiotic [16]. In the present case, gentamicin was added to a beta-lactam antibiotic when the echocardiographic images showed the presence of multiple vegetant lesions on the mitral valve.

Streptococcus pyogenes can also produce multiple exotoxins that have the potential to cause end-organ damage or trigger the release of cytokines that can cause tissue injury. Many virulence determinants have been identified using genomic and molecular analyses of Streptococcus pyogenes strains, many of which are related to the processes of adhesion and colonization, innate immune resistance, and the ability to facilitate degradation of tissue barriers and spread in the human body [17]. The key factor of the pathogenicity of Streptococcus pyogenes is the M protein: this surface-exposed antigenic protein is involved in the adhesion of the bacterium to human tissues and in preventing phagocytosis. The Streptococcus pyogenes strain G773 was sequenced in a case of acute endocarditis in a child [11]. This strain possesses a combination of various pathogenetic factors: the M protein is able to bind the $\mathrm{C} 4 \mathrm{~b}$-binding protein and immunoglobulin; produces bacteriocins (proteins with bactericidal activity); and has the capacity to colonize the host by eliminating other bacterial species that share the same environment. In seven cases of endocarditis due to

Streptococcus pyogenes, fibronectin and fibrinogen-binding genes correlated with the severity of disease manifestations such as an acute onset of illness, large vegetations, the presence of frequent embolic complications, and a high mortality rate. The Streptococcus pyogenes endocarditis strains showed an overrepresentation of several of the fibronectin and fibrinogen binding genes, which probably indicates that the ability to bind the fibronectin is an important step in the development of endovascular streptococcal infections [10].

\section{Conclusions}

When treated with appropriate antimicrobial therapy and supportive therapy promptly, even a severe presentation of Streptococcus pyogenes endocarditis can have excellent outcomes. In our case, antibiotic treatment was associated with clinical recovery. However, because of the relative infrequency of IE caused by Streptococcus pyogenes together with the lack of studies in children, decisions regarding surgical intervention are best individualized. Epidemiological data and more extensive characterization of virulence factors with a genomic analysis of isolated bacteria and molecular screening are both necessary to further elucidate the pathogenic mechanisms. 


\section{Additional Information}

\section{Disclosures}

Human subjects: Consent was obtained by all participants in this study. Conflicts of interest: In compliance with the ICMJE uniform disclosure form, all authors declare the following:

Payment/services info: All authors have declared that no financial support was received from any organization for the submitted work. Financial relationships: All authors have declared that they have no financial relationships at present or within the previous three years with any organizations that might have an interest in the submitted work. Other relationships: All authors have declared that there are no other relationships or activities that could appear to have influenced the submitted work.

\section{References}

1. Walker MJ, Barnett TC, McArthur JD, et al.: Disease manifestations and pathogenic mechanisms of group A streptococcus. Clin Microbiol Rev. 2014, 27:264-301.

10.1128/CMR.00101-13

2. Weidman DR, Al-Hashami H, Morris SK: Two cases and a review of streptococcus pyogenes endocarditis in children. BMC Pediatr. 2014, 14:227. 10.1186/1471-2431-14-227

3. Khairat O: Myocardial abscess and acute endocarditis due to streptococcus pyogenes . Can Med Assoc J. 1961, 85:1403.

4. Burkert T, Watanakunakorn C : Group A streptococcus endocarditis: report of five cases and review of literature. J Infect. 1991, 23:307-316.

5. Merlin E, Souteyrand G, Dauphin C, et al.: Streptococcus pyogenes endocarditis following varicella: A case report. Arch Pédiatrie. 2004, 11:122-125.

6. Almas A, Tariq M: Beta-hemolytic streptococcus group A endocarditis: a rare clinical presentation. J Coll Physicians Surg Pak. 2008, 18:37-39.

7. Yesilkaya A, Kurt Azap O, Pirat B, Gultekin B, Hande A: A rare cause of endocarditis: streptococcus pyogenes. Balkan Med J. 2012, 29:331-333. 10.5152/balkanmedj.2012.053

8. Branch J, Suganami Y, Kitagawa I, Stein GH, Tanaka E: A rare case of group A streptococcal endocarditis with absence of valvular vegetation. Intern Med. 2010, 49:1657-1661. 10.2169/internalmedicine.49.3711

9. Suzuki T, Mawatari M, Iizuka T, et al.: An ineffective differential diagnosis of infective endocarditis and rheumatic heart disease after streptococcal skin and soft tissue infection. Intern Med. 2017, 56:2361-2365. 10.2169/internalmedicine.8411-16

10. Oppegaard O, Mylvaganam H, Skrede S, Jordal S, Glambek M, Kittang BR: Clinical and molecular characteristics of infective $\beta$-hemolytic streptococcal endocarditis. Diagn Microbiol Infect Dis. 2017, 89:135-142. 10.1016/j.diagmicrobio.2017.06.015

11. Beye M, El Karkouri K, Labas N, Raoult D, Fournier P-E: Genomic analysis of a streptococcus pyogenes strain causing endocarditis in a child. New Microbes New Infect. 2017, 17:1-6. 10.1016/j.nmni.2017.01.007

12. Spoladore R, Agricola E, D'Amato R, Durante A, Fragasso G, Margonato A: Isolated native tricuspid valve endocarditis due to group A $\beta$ hemolytic streptococcus without drug addiction. J Cardiovasc Med (Hagerstown). 2017, 18:691-693. 10.2459/JCM.0b013e32833cdc54

13. Wang SC, Torosoff MT, Smith RP, Coates AD: Streptococcus pyogenes meningitis and endocarditis in a patient with prosthetic mitral valve. J Cardiol Cases. 2017, 16:82-84. 10.1016/j.jccase.2017.05.010

14. Inoue K, Hagiwara A, Kimura A, Ohmagari N: A complication of meningitis and infective endocarditis due to streptococcus pyogenes. BMJ Case Rep. 2017, 2017:2017-2208. 10.1136/bcr-2017-220847

15. Lefort A, Mainardi JL, Selton-Suty C, Casassus P, Guillevin L, Lortholary O: Streptococcus pneumoniae endocarditis in adults: a multicenter study in France in the era of penicillin resistance (1991-1998). Medicine. 2000, 79:327-337. 10.1097/00005792-200009000-00006

16. Baddour LM, Wilson WR, Bayer AS, et al.: Infective endocarditis in adults: diagnosis, antimicrobial therapy, and management of complications: a scientific statement for healthcare professionals from the American heart association. Circulation. 2015, 132:14351486. 10.1161/CIR.0000000000000296 


\section{Cureus}

17. Bidet P, Bonacorsi S: Streptococcus pyogenes pathogenic factors . Arch Pediatric. 2014, 21:5461. 10.1016/S0929-693X(14)72261-4 